\title{
FLEXURAL SIMULATION ANALYSIS OF RC T-GIRDERS STRENGTHED WITH POLYURETHANE CEMENT- PRESTRESSED STEEL WIRE ROPES
}

\author{
Kexin Zhang ${ }^{1}$, Xinyuan Shen ${ }^{1}$, Dachao Li', Wenyu Hou ${ }^{1}$, Fei Teng ${ }^{1}$, Xing wei \\ Xue ${ }^{1}$ and Quansheng Sun ${ }^{2}$
}

1. Shenyang Jianzhu University, School of Traffic Engineering, Department of Bridge Engineering, Shenyang, No.25 hunnan Zhong Road, China; jt_zkx@sjzu.edu.cn

2. Northeast Forestry University, School of Civil Engineering, Department of Bridge Engineering, Harbin, No.26 Hexing Road, China; hrbsqs@126.com

\begin{abstract}
To verify the effectiveness of polyurethane cement-prestressed steel wire ropes for flexural reinforcement of reinforced concrete T-girders, this paper conducts flexural test research on 7 pieces of T-girder specimens. Through the ABAQUS finite element program to build a model for numerical simulation, the results show polyurethane cement prestressed steel wire rope reinforcement can significantly increase the yield load and ultimate load of reinforced girders. Taking a girder in the test $(20 \mathrm{~mm}$ reinforcement thickness of polyurethane cement) as an example, yield load and ultimate load increased by $61.5 \%$ and $102.3 \%$ compared to unreinforced girder. The finite element model calculation results of T-girder bending reinforcement are in good agreement with the bending reinforcement test, and the error is only about $2 \%$. For different strength concrete, the yield load increases slightly with the increase of concrete strength. For T-girders with different reinforcement ratios, the bearing capacity of strengthened girders changes significantly with the increase of longitudinal reinforcement ratio. The yield load of girders with reinforcement ratio of $1.82 \%$ and $1.35 \%$ is $29.84 \%$ and $65.85 \%$ higher than that of girders with reinforcement ratio of $0.91 \%$. The yield deflection is $13.18 \%$ and $3.99 \%$ higher than that of girders with reinforcement ratio of $0.91 \%$. It can be concluded that the bending reinforcement method of polyurethane cement prestressed steel wire ropes can effectively strengthen the main girder and ensure the structural safety.
\end{abstract}

\section{KEY WORDS}

Finite element analysis (FEA), Finite element modelling, T-girder strengthening, Polyurethane cement-prestressed steel wire ropes

\section{BACKGROUND}

Due to the rapid increase of vehicle load and the influence of natural conditions, a series of defects are inevitable in the bridge structure. These diseases will directly affect the stiffness and bearing capacity of the old bridge structure [1-3]. Practice has shown that the load-bearing capacity of old bridge structures can be restored and improved by using appropriate strengthening methods [4-5]. The accurate simulation analysis of cracking damage and bearing capacity of concrete girder bridge can provide a certain theoretical basis for the safety 


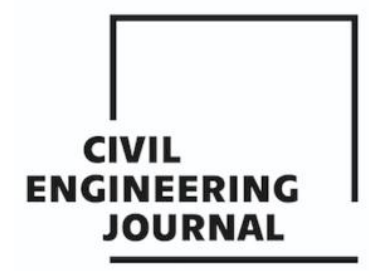

Article no. 69

THE CIVIL ENGINEERING JOURNAL 4-2021

evaluation, maintenance and reinforcement of existing bridges [7-9]. With the development of electronic computers, the emergence and application of finite elements can provide solid and nonlinear analysis for reinforced concrete structures, which greatly promotes the efficiency of simulation analysis. Nowadays, finite element software simulation has become one of the indispensable work in bridge test [10], [11].

In recent years, many scholars have conducted experimental analyses on the mechanical properties and reinforcement effects of reinforced concrete structures by means of finite element procedures. Cao Ming[12] used the finite element software ABAQUS to perform nonlinear analysis of reinforced concrete structures, summarized the basic principles and characteristics of the concrete principal structure model, and applied the calculation method to a finite element analysis of a simply supported girder to verify the reliability of the method. Yuan Ming [13] et al used a nonlinear finite element method to simulate and analyze the plastic damage of concrete box girders, and compared the simulation results with the experimental data to verify. The feasibility of introducing damage factors into the nonlinear analysis method of prestressed concrete box girder is verified, and the structural flexural and shear properties and damage characteristics can be accurately obtained; Zhang Haixia[14] et al used ABAQUS finite element software to apply different cell types for concrete, CFRP bars or laths and binder, especially Spring 2 nonlinear spring cells to simulate the bonding effect of concrete with embedded CFRP bars or laths on the surface. Through finite element analysis, they obtained more accurate limit values of pull-out specimens, and correctly simulated the stress process of strengthened girders. Xu Chuanxue[15] et al clarified the main influencing factors by analyzing the long-term deformation of in vitro prestressed reinforced girders, and analyzed the law and degree of influence of each influencing factor on the long-term stiffness of reinforced concrete girders. Then the simulation results of various factors are given by finite element software to verify the reliability of analysis and simulation. Their research provides a reliable theoretical basis for the reinforcement of external prestress.

In this paper, 7 reinforced concrete T-section girders are strengthened by polyurethane cement prestressed steel wire rope flexural strengthening method for experimental study. Based on the plastic damage model, the nonlinear finite element analysis of reinforced concrete structure is carried out by using the test aided finite element software ABAQUS. Then, the parameters such as the number of steel wires embedded in polyurethane cement, the thickness of reinforced polyurethane cement, concrete strength grade and section reinforcement ratio are compared and analyzed.

\section{T-GIRDER FLEXURAL STRENGTHENING RESULTS}

\section{Overview of Flexural Reinforcement Test}

A total of $7 \mathrm{~T}$-section simply supported girder specimens were tested in this section. The concrete for all specimens was made according to the same mix ratio. The specimens are of the same size, with an overall length of $3000 \mathrm{~mm}$, a net span of $2700 \mathrm{~mm}$, a shear-bend section length of $900 \mathrm{~mm}$ and a pure-bend section length of $900 \mathrm{~mm}$. The longitudinal tensile steel bars are two $18 \mathrm{~mm}$ diameter tertiary rebar, the longitudinal reinforcement rate is $0.91 \%$, the measured yield strength is $418 \mathrm{MPa}$, and the erection reinforcement is $10 \mathrm{~mm}$ diameter secondary rebar, the measured yield strength is $250 \mathrm{MPa}$. In order to prevent insufficient shear strength, the configuration along the length of the specimen is $8 \mathrm{~mm}$ diameter first-class light round reinforcement, pure bending section spacing of $150 \mathrm{~mm}$, shear bending section spacing of $80 \mathrm{~mm}$. The specific parameters of the cross-section are shown in Figure 1. 


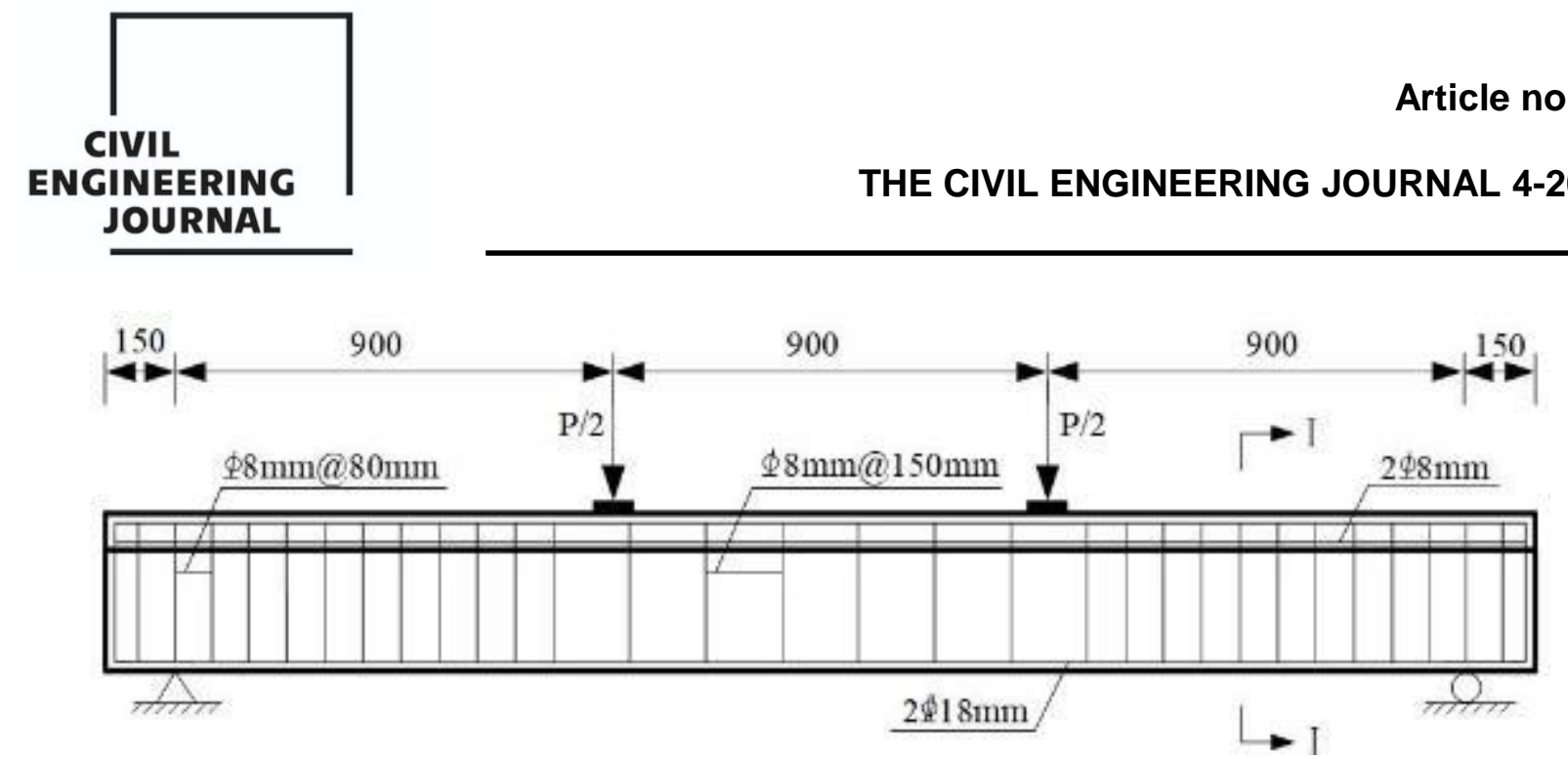

Fig. 1 - Longitudinal section size and reinforcement (unit: $\mathrm{mm}$ )

In order to study the influence of embedded materials of prestressed steel wire ropes on the performance of strengthened girders, a control girder without reinforcement is set up. The reinforced girders are divided into two parts, one part is the prestressing steel wire rope reinforced girder, 4 pieces in total. The other part is polyurethane cement prestressed steel wire ropes reinforced girders, 7 pieces in total, with specific parameters and girder numbers as shown in Table 1.

Tab. 1 - Reinforcement parameters of girders

\begin{tabular}{|c|c|c|c|c|c|c|}
\hline Groups & $\begin{array}{l}\text { Girder } \\
\text { number }\end{array}$ & $\begin{array}{c}\text { Number } \\
\text { of wire } \\
\text { ropes }\end{array}$ & $\begin{array}{l}\text { Pre-stress } \\
\quad(\mathrm{MPa})\end{array}$ & $\begin{array}{l}\text { Embedded } \\
\text { materials }\end{array}$ & $\begin{array}{l}\text { Material } \\
\text { thicknes } \\
\mathrm{s}(\mathrm{mm})\end{array}$ & Anchorage? \\
\hline Control girder & $\mathrm{CB}$ & - & - & - & - & No \\
\hline $\begin{array}{c}\text { prestressed } \\
\text { steel wire ropes }\end{array}$ & $\mathrm{A} 2$ & 5 & 700 & Mortar & 20 & Yes \\
\hline \multirow{5}{*}{$\begin{array}{l}\text { prestressed } \\
\text { steel wire ropes- } \\
\text { polyurethane } \\
\text { cement }\end{array}$} & A4 & 0 & 700 & PUC & 20 & No \\
\hline & A5 & 5 & 700 & PUC & 20 & Yes \\
\hline & A8 & 5 & 700 & PUC & 30 & Yes \\
\hline & A9 & 2 & 700 & PUC & 20 & Yes \\
\hline & A9-1 & 2 & 700 & PUC & 25 & Yes \\
\hline
\end{tabular}

\section{Test measurements}

Strain gauges were set up on concrete, steel reinforcement, steel wire rope, polyurethane cement and composite mortar to measure the material strain in each part. Four strain gauges affixed to the two tensile main reinforcement bars, arranged in the loading point section and the span section, respectively. Each wire rope in the pure bending section of the loading area to arrange 1 specification of strain gauges, staggered arrangement of the strain gauges of each wire rope. Polyurethane cement material is arranged with 4 strain gauges, 2 strain gauges are arranged at the bottom of the girders. The strain gauges of the composite mortar were arranged in the same form as the polyurethane cement, and the specific strain measurement arrangement positions are shown in Figure 2 and Figure 3. 


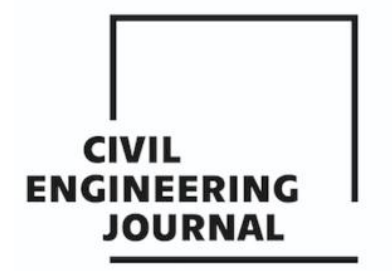

Article no. 69

THE CIVIL ENGINEERING JOURNAL 4-2021

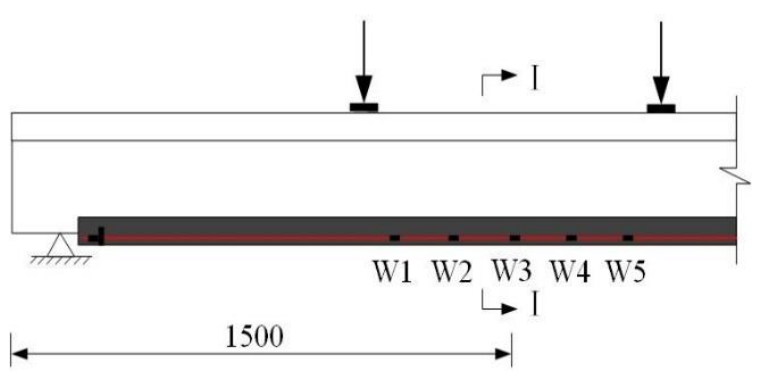

Fig.2 - Longitudinal arrangement of strain gauges in steel wire ropes

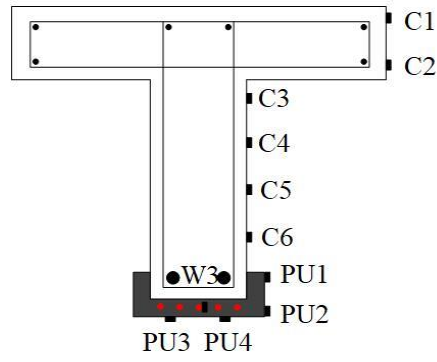

Fig.3 - Strain gauges of steel wire ropes arrangement (cross section)

\section{Test results and analysis}

Load-deflection curves of girders are shown in Figure 4. The reinforced girders first exhibit a linear elastic phenomenon like that of the unreinforced girders, but with a higher initial stiffness. When the load reaches $150 \mathrm{kN}$, the slope of the curve starts to decrease and the wire rope starts to reach the nominal yield strength. Despite the decrease in slope, the stiffness still maintains a high level. Compared with the A2 girder reinforced with cement mortar prestressed steel wire rope, the A5 girder has higher load carrying capacity and overall stiffness. Girder A4 is a polyurethane cement reinforced girder, and there is no prestressing steel wire rope in the polyurethane cement. Girder A4 has greater initial stiffness than the control girder, but slightly less stiffness than girder A5.

The load-deflection curves of girders A5, A8, A9 and A9-1 are shown in Figure 5. Both A9 and $A 9-1$ girders have 2 prestressing steel wires. Both $A 5$ and $A 8$ girders have 5 prestressing steel wires. These two control groups differ only in the thickness of the polyurethane cement material. Compared with A5 and A9 girders with $20 \mathrm{~mm}$ thickness polyurethane cement, A8 and A9-1 girders have higher structural stiffness. The thickened polyurethane cement material also has a more significant effect on limiting cracks during loading, reducing the formation and expansion of cracks and increasing the overall stiffness of the girder. In addition, the deflections of girder A9-1 and A8 were reduced compared with those of girder A9 and A5, respectively. Due to the different number of wire ropes, but the reduction was not significant.

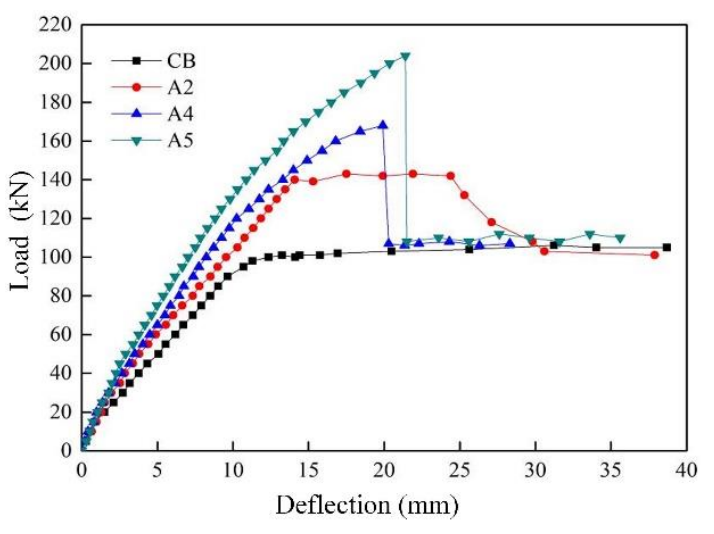

Fig.4 -Different load-deflection curves

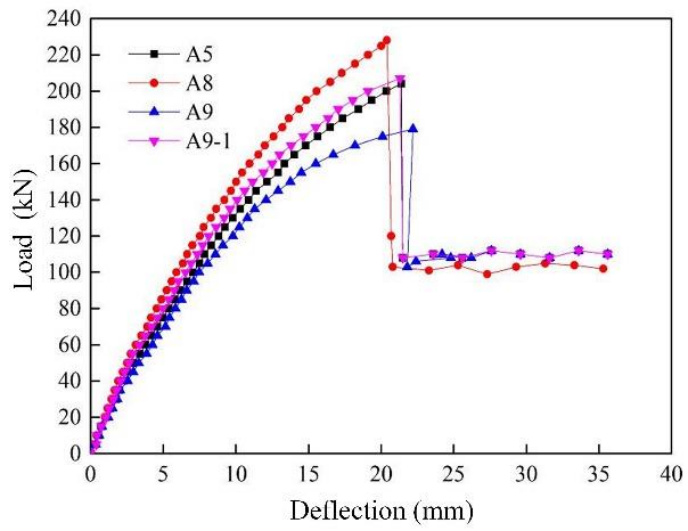

Fig.5 - Different load-deflection curves

When girder A5 reaches a yield load of $120 \mathrm{kN}$, the net strain increases in the wire rope after subtracting the initial tension strain is $2155 \mu \varepsilon$. Under this load, the net increase of the 


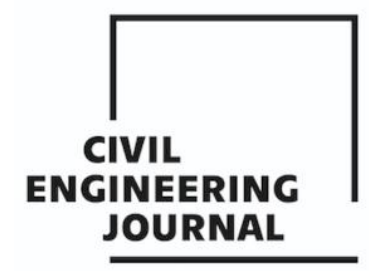

Article no. 69

THE CIVIL ENGINEERING JOURNAL 4-2021

wire rope of girder A2 has risen to $2804 \mu \varepsilon$, which can indicate that the polyurethane cement material embedded in the prestressed wire rope can delay the yielding of the girder reinforcement and effectively increase the load carrying capacity of the main girder when the wire rope strains of both types of girders reach the same level.

The A9 and A9-1 girder reinforcement, wire rope and polyurethane cement material strains are shown in Figure 9. Both reinforcement girders are arranged with 2 prestressing steel ropes, and the A9 and A9-1 girders are embedded in $20 \mathrm{~mm}$ and $25 \mathrm{~mm}$ polyurethane cement materials respectively. From the graphs, it can be seen that the load-strain curves of the reinforcement, wire ropes and polyurethane cement materials in the two girders have similar trends. Since the thickness of the steel wire rope embedded in the polyurethane cement material in girder A9-1 is $5 \mathrm{~mm}$ greater than that of $A 9$, the strain on the steel reinforcement, steel wire rope and polyurethane cement in girder A9-1 is smaller than that of girder $A 9$ under the same load. As the wire rope enters the nominal yield state, the tensile strain difference between the two girders of polyurethane cement material under the same load becomes progressively larger, due to the steel bars entering the yield state, when the prestressing wire rope in the girder is also approaching the nominal yield strength.

Tab. 2 - Cracking load, yield load and ultimate load

\begin{tabular}{|c|c|c|c|c|c|c|c|}
\hline Groups & $\begin{array}{c}\text { Girder } \\
\text { number }\end{array}$ & $\begin{array}{c}\text { Cracking } \\
\text { strength } \\
(\mathrm{kN})\end{array}$ & $\begin{array}{c}\text { Increase } \\
\text { proportion } \\
(\%)\end{array}$ & $\begin{array}{c}\text { Yield } \\
\text { strength } \\
(\mathrm{kN})\end{array}$ & $\begin{array}{c}\text { Increase } \\
\text { proportion } \\
(\%)\end{array}$ & $\begin{array}{c}\text { Ultimate } \\
\text { strength } \\
(\mathrm{kN})\end{array}$ & $\begin{array}{c}\text { Increase } \\
\text { proportion } \\
(\%)\end{array}$ \\
\hline Control girder & $\mathrm{CB}$ & 20.0 & - & 74.3 & - & 101.0 & - \\
\hline $\begin{array}{c}\text { Prestressed } \\
\text { wire ropes }\end{array}$ & $\mathrm{A} 2$ & 40.0 & 100.0 & 96.7 & 30.1 & 141.3 & 39.9 \\
\hline \multirow{2}{*}{$\begin{array}{c}\text { Polyurethane } \\
\text { cement- } \\
\text { prestressed } \\
\text { wire ropes }\end{array}$} & $\mathrm{A} 4$ & 25.0 & 25.0 & 98.8 & 33.0 & 168.7 & 67.0 \\
\cline { 2 - 8 } & $\mathrm{A} 5$ & 45.0 & 125.0 & 120.0 & 61.5 & 204.3 & 102.3 \\
\cline { 2 - 8 } & $\mathrm{A} 9$ & 55.0 & 175.0 & 137.0 & 84.4 & 228.5 & 126.2 \\
\cline { 2 - 8 } & $\mathrm{A} 9-1$ & 30.0 & 50.0 & 110.3 & 48.5 & 179.0 & 77.2 \\
\hline
\end{tabular}

\section{FINITE ELEMENT SIMULATION ANALYSIS OF FLEXURAL REINFORCEMENT}

\section{Model parameter selection}

\section{(1) Concrete stress-strain curve}

The ABAQUS plastic damage model can simulate the stiffness recovery, damage, crack development and closure behavior of concrete structural members under reciprocal loading[16]. The plastic damage model is chosen for modeling the flexural test of polyurethane cement-prestressed steel wire ropes. The plastic damage model is modeled using the yield strengthening criterion and the flow law, which are used to calibrate the parameters in the model.

In order to make the model simulation results closer to the actual situation, the concrete uniaxial stress-strain relationship and loading stress paths need to be provided. The concrete intrinsic structure relationship given by the code[17] was used as the stress-strain relationship. The material elasticity modulus $E$ and the elastic stress are $\sigma_{t 0}\left(\sigma c_{0}\right)$ used to determine the stress-strain relationship in the elastic phase of the material, and the material stress-strain 
relationship provided by the code is used to determine the relationship in the inelastic phase. Then the expressions are respectively:

Under tension:

$$
y=\frac{x}{q(x-1)^{1.7}+x} \quad x>1
$$

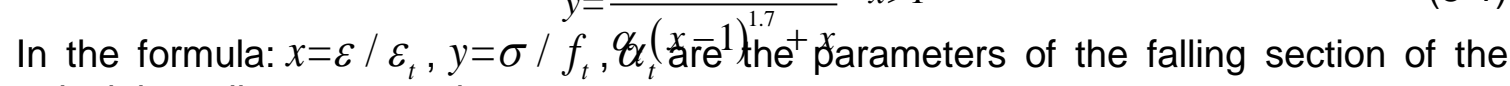
uniaxial tensile stress-strain curve.

Under pressure:

$\left\{\begin{array}{c}y=\alpha_{a} x+\left(3-2 \alpha_{a}\right) x^{2}+\left(\alpha_{a}-2\right) x^{3} \\ x\end{array} \quad x \leqslant 1\right.$

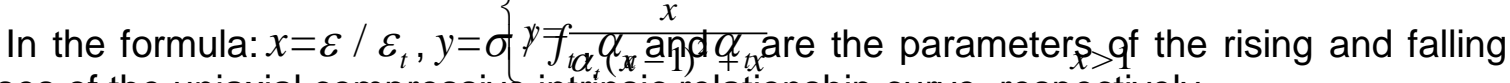
phases of the uniaxial compressive intrinsic relationship curve, respectively.

\section{(2) Damage factors}

Concrete research scholars have used the following methods to calculate the damage factor of the material [18-20], and the results obtained are also relatively good, so the damage factor is calculated in this paper according to the equation in the literature [18]. The damage factors in the literature [18] for uniaxial compression and tension are calculated as:

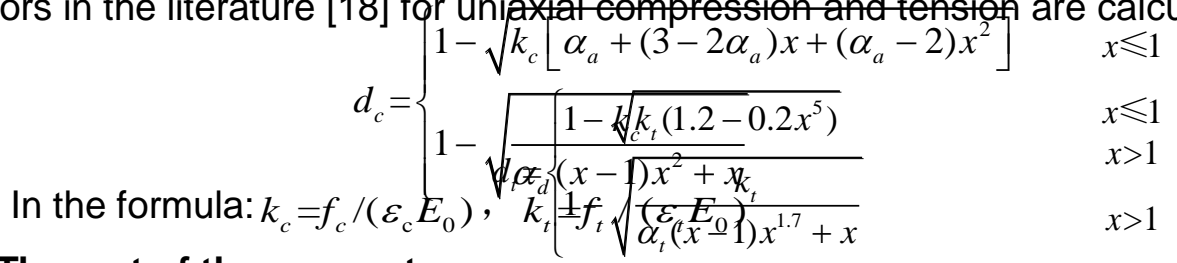

\section{(3) The rest of the parameters}

The selection of parameters in the model affects the convergence of the calculated results. In this paper, the coefficient of viscosity of concrete material is taken as 0.001 and the expansion angle $\varphi$ is taken as $35^{\circ}$. The plastic damage parameters of C40 concrete are shown in Table 3.

Tab.3: The plastic damage parameters of $C 40$ concrete

\begin{tabular}{|c|c|c|c|c|}
\hline$\varepsilon$ & $\varphi$ & $\sigma_{b 0} / \sigma_{c 0}$ & $\mu$ & $K_{c}$ \\
\hline 0.100 & 35.000 & 1.160 & 0.001 & 0.667 \\
\hline
\end{tabular}

Intrinsic relationship between reinforcement, wire ropes, and polyurethane cement materials:

In the finite element analysis of flexural reinforcement, in order to make the model both simple and better simulate the reinforcing effect of the reinforcement, only the stress-strain relationship of the reinforcement in the monotonic loading mode is considered in the model building process. At this time, the reinforcement principal model curve includes elastic section, yield section, and hardening phase. The elastic-plastic hardening model is used in Figure 8, where the bond slip between the reinforcement and concrete is not considered in the model. The stress-strain curves of the wire rope material and the polyurethane cement material were 
measured using the actual curves of this test with reference to the literature[21-23], and the test results are shown in Figure 9 and Figure 10.

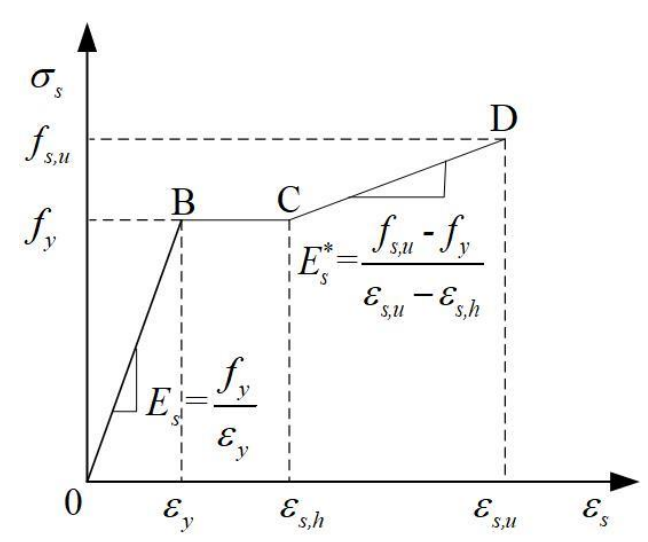

Fig. 8 - Steel Bar Stress - Strain Curves (Elastic-plastic reinforcement model)

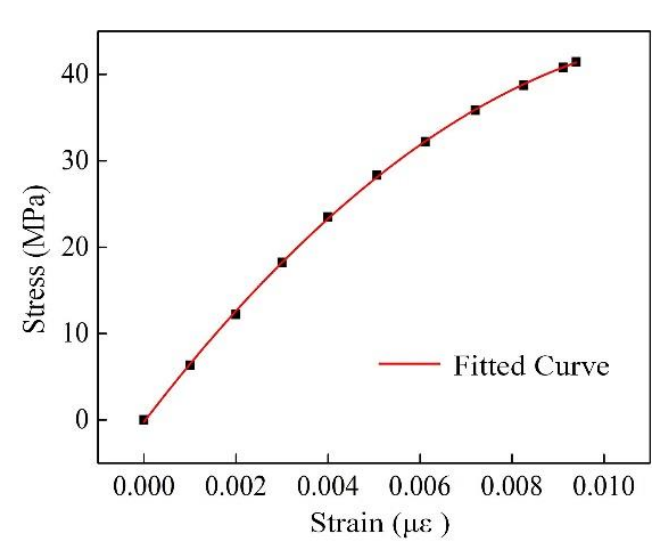

Fig.9 - Fitting curve of strain-stress (PUC)

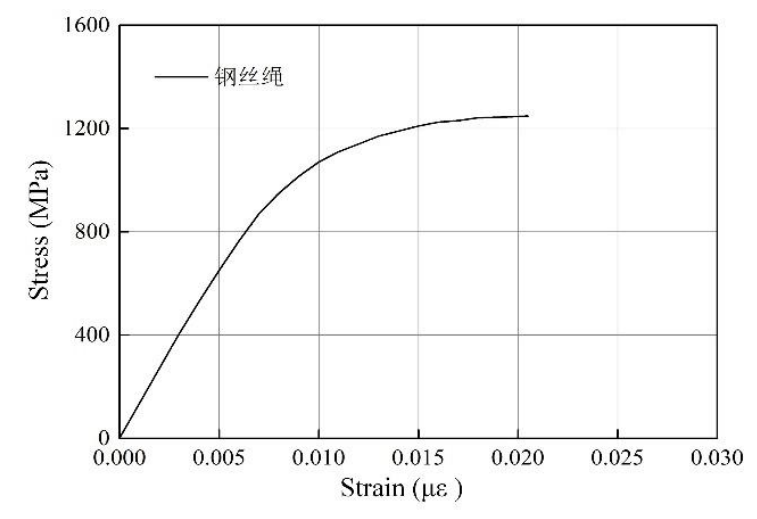

Fig.10 - Wire Ropes Stress-strain Curves

\section{Finite element simulation of reinforced concrete girder flexural resistance}

The finite element model in this section is used to compare the test girder CB girder and to verify the effect of numerical simulation. The finite element units are selected as follows:

Solid units are selected for concrete, bearing plates; Wire units are selected for main reinforcement and hoop bars.

Poisson's ratio: concrete: 0.2 , bearing plates: 0.25 .

In the model, the concrete and bearing plates are connected with Tie, and the main reinforcement and rectangular hoop reinforcement in the concrete are embedded in Embedded region. Constraints are added to the centerline of the mat, with vertical constraints applied at one end and horizontal and vertical constraints at the other end, to simulate the simply supported girder boundary conditions. The cell mesh size is $20 \mathrm{~mm} \times 20 \mathrm{~mm} \times 20 \mathrm{~mm}$, and the mesh of the unreinforced girder is divided as shown in Figure 11. The model does not consider the bond slip between the reinforcement and concrete. 


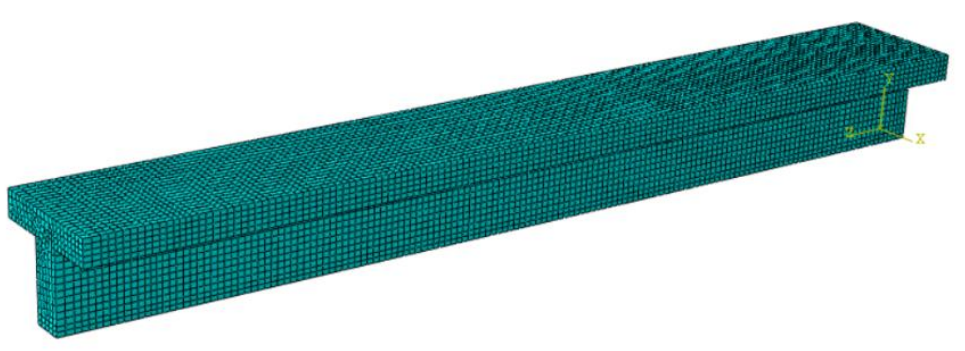

Fig. 11 - Finite element model of the $T$ girder

In the following, we will use "FEM-CB" to represent the finite element model and "EXPCB" to replace the actual model, and the calculation results are as follows:

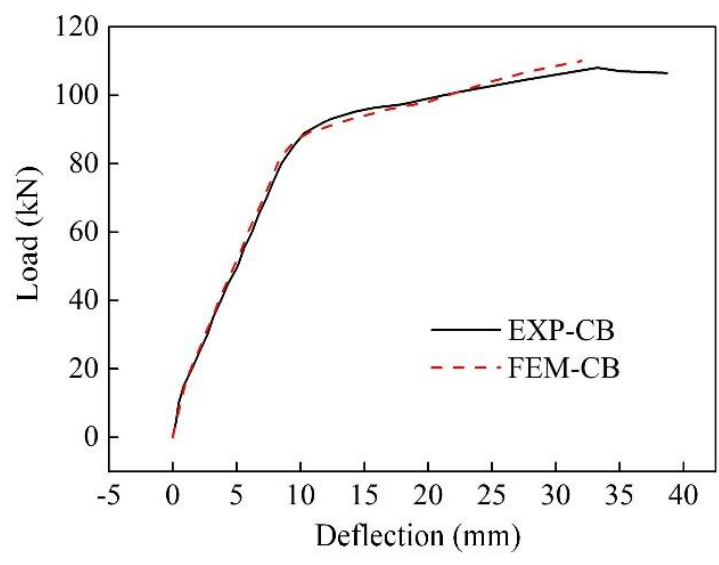

Fig. 12 - Load-deflection curve

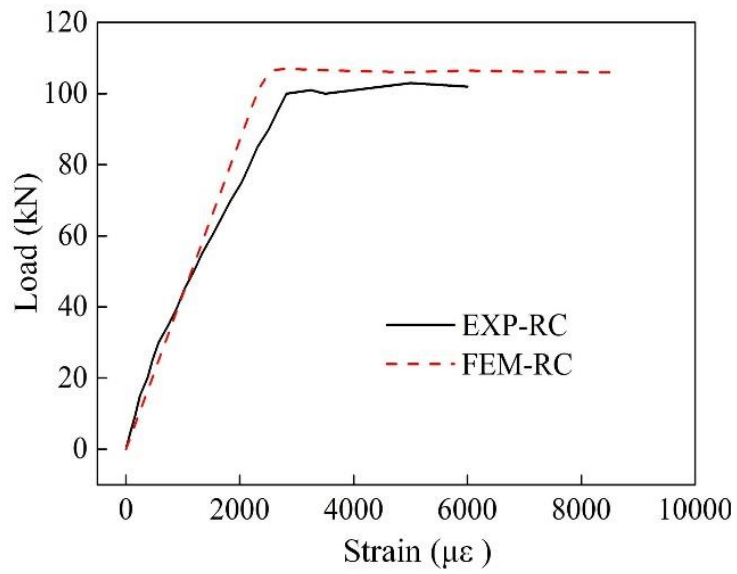

Fig. 13 - Load-steel strain curve

Tab. 4 - Calculated value of Abaqus and test value comparison

\begin{tabular}{|c|c|c|c|}
\hline $\begin{array}{c}\text { Specimens } \\
\text { number }\end{array}$ & $\begin{array}{c}\text { Yield } \\
\text { strength/kN }\end{array}$ & $\begin{array}{c}\text { Yield } \\
\text { deflection/mm }\end{array}$ & $\begin{array}{c}\text { Ultimate } \\
\text { strength/kN }\end{array}$ \\
\hline EXP-CB (CB) & 78 & 8.2 & 106 \\
\hline FEM-CB & 80 & 8.0 & 108 \\
\hline Error & 0.026 & -0.024 & 0.019 \\
\hline
\end{tabular}

As seen from the test curve in Figure 12 and the data in Table 4: the calculated result of Abaqus program is similar to the test result. When the longitudinal reinforcement in the span section yields, the deflection of the girder increases rapidly and the width of the crack expands continuously. The area of the concrete compressed zone gradually decreases with the extension of the crack, but the compressive stress undergone keeps increasing, and the calculation is terminated when the girder deflection exceeds the test deflection. From the data in Table 4 of the test curve: it can be seen that the error of the yielding load is only $2.6 \%$ for 
the FEM simulated values compared with the test values; Deflection error at the yield point of only $2.4 \%$; The error for the ultimate load is only $1.9 \%$.

Figure 13 shows the comparative load-strain curves of EXP-RC girder and FEM-RC. From the figure, it can be seen that the calculated curve of ABAQUS program and the test curve basically match. Compared with the experimental curves, there are some differences between the ABAQUS simulation curves and the experimental test curves. The main difference is that there is a certain difference between the intrinsic structure relationship of the bars entered in the model and the actual curve relationship of the bars, and the curve relationship obtained from the test is the test result of one bar. The values of the reinforcement entered is the average of the test results of the two bars. The actual test result curve is short, which is caused by the failure or breakage of the strain gauge during the actual loading process.

\section{Comparative finite element analysis of flexural reinforced girders}

The finite element model of the prestressed wire rope polyurethane cement reinforced girder was established based on the test data of the reinforced T-girder in the previous section and numerical analysis was performed. The reinforced wire rope diameter is $4 \mathrm{~mm}$, and the unit is selected as Wire, which is simplified according to the actual curve of stress-strain relationship. Finite element model of reinforced girder can be seen in Figure 14, and steel bars model are in Figure 15. Polyurethane cement material, Solid unit was selected and the stress-strain curve relationship was adopted from the measured axial tensile curve Figure 15. The initial tensile strength of the wire rope is achieved by the cooling method and is embedded in the polyurethane cement material by means of embedded. Tie is chosen for the contact between the polyurethane cement material and the concrete.

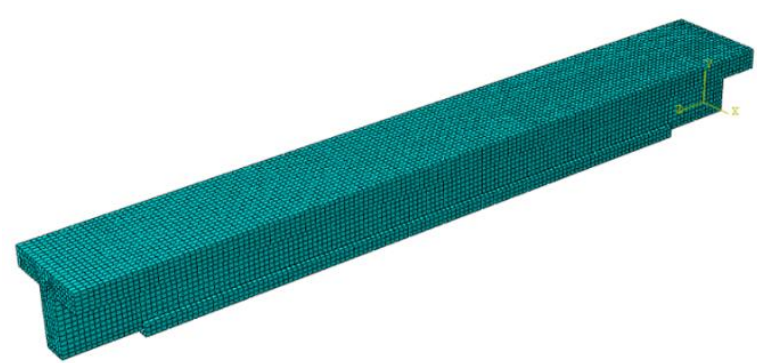

Fig. 14 - Finite element model of reinforced girder

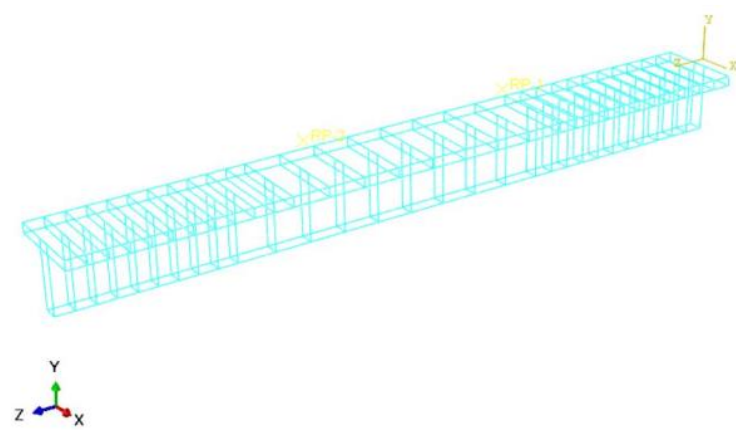

Fig. 15 - Finite element model of reinforcement cage

\section{Finite element calculation results of flexural strengthening test girder}

Three girders A5, A8 and A9 with different thicknesses of polyurethane cement and different numbers of wire ropes were selected as representatives for finite element calculations of flexural strengthening test girders. The ABAQUS finite element simulation results and test results of reinforced girders A5, A8 and A9 are shown in Table 5 below. The errors of both results are within $5 \%$. 
Article no. 69

THE CIVIL ENGINEERING JOURNAL 4-2021

Tab. 5 - Comparison table between simulated and experimental value (Strengthened girders)

\begin{tabular}{|c|c|c|c|c|}
\hline $\begin{array}{c}\text { Specimen } \\
\text { number }\end{array}$ & $\begin{array}{c}\text { Yield strenth } \\
(\mathrm{kN})\end{array}$ & $\begin{array}{c}\text { Yield deflection } \\
(\mathrm{mm})\end{array}$ & $\begin{array}{c}\text { Ultimate strenth } \\
(\mathrm{kN})\end{array}$ & $\begin{array}{c}\text { Fracture deflection of } \\
\text { reinforcement layer }(\mathrm{mm})\end{array}$ \\
\hline EXP-A5 & 120.0 & 8.82 & 204.3 & 21.4 \\
\hline FEM-A5 & 123.0 & 9.03 & 208.0 & 20.4 \\
\hline Error & $2.5 \%$ & $2.3 \%$ & $1.8 \%$ & $4.7 \%$ \\
\hline EXP-A8 & 137.0 & 9.08 & 228.5 & 20.4 \\
\hline FEM-A8 & 142.0 & 9.26 & 235 & 21.0 \\
\hline Error & $3.6 \%$ & $2.0 \%$ & $2.8 \%$ & $3.9 \%$ \\
\hline EXP-A9 & 110.3 & 7.48 & 179.0 & 22.2 \\
\hline FEM-A9 & 107.2 & 7.81 & 175.3 & 21.6 \\
\hline Error & $-2.8 \%$ & $4.4 \%$ & $2.1 \%$ & $-2.7 \%$ \\
\hline
\end{tabular}

The finite element calculation clouds of specimen A5 are shown in Figure $16 \sim$ Figure 19.
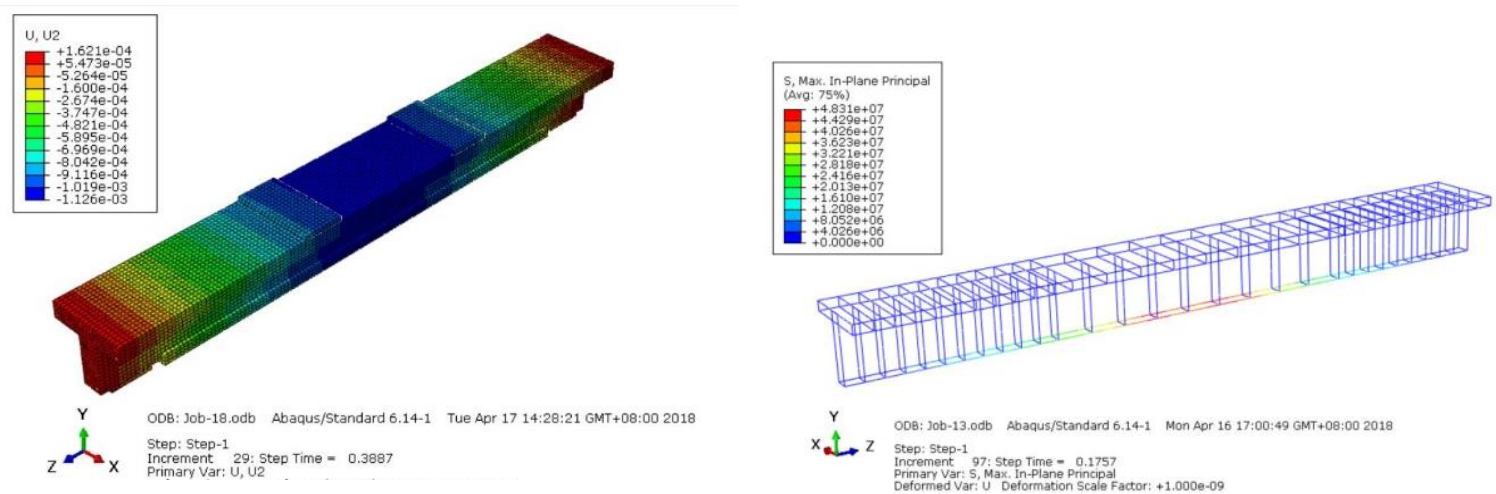

Fig.16 -Displacement cloud diagram of A5 Fig.17 - Reinforcement stress cloud diagram of A5
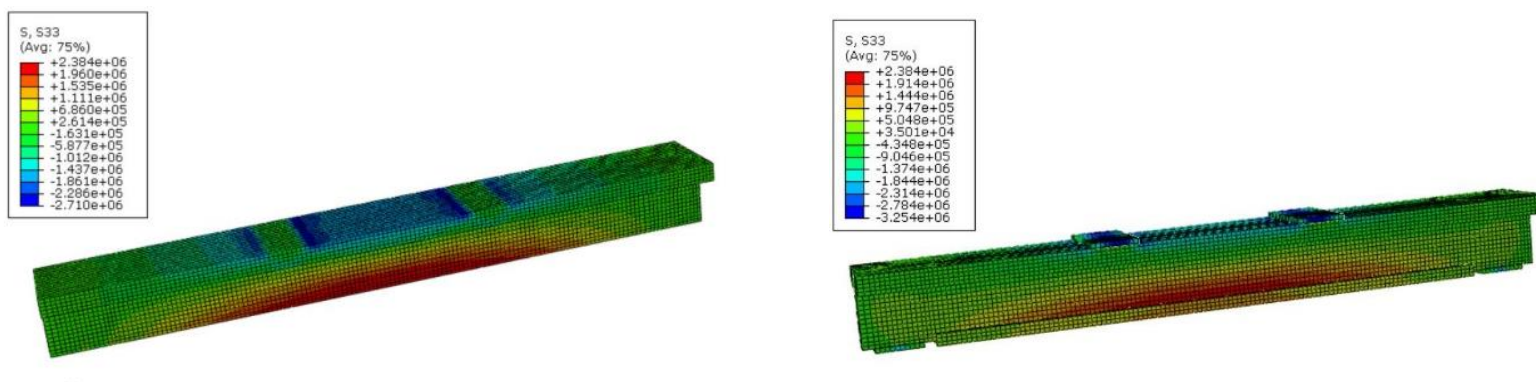

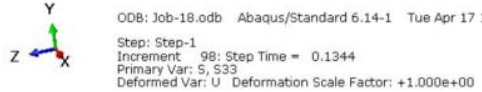

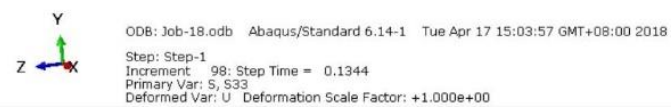

Fig.18 - Concrete stress cloud diagram of A5

Fig. 19 - PUC stress cloud diagram of A5 


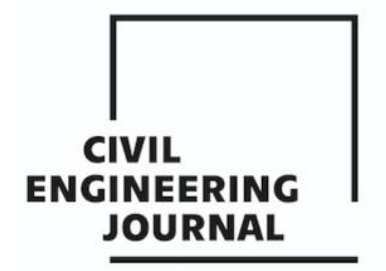

Article no. 69

THE CIVIL ENGINEERING JOURNAL 4-2021

As shown in Figure 20, the finite element calculation curve of specimen A5 is compared with the test curve. The finite element calculation curves formed by the member deflection, PUC strain, steel strain and concrete compression strain similar to the experimental test result.

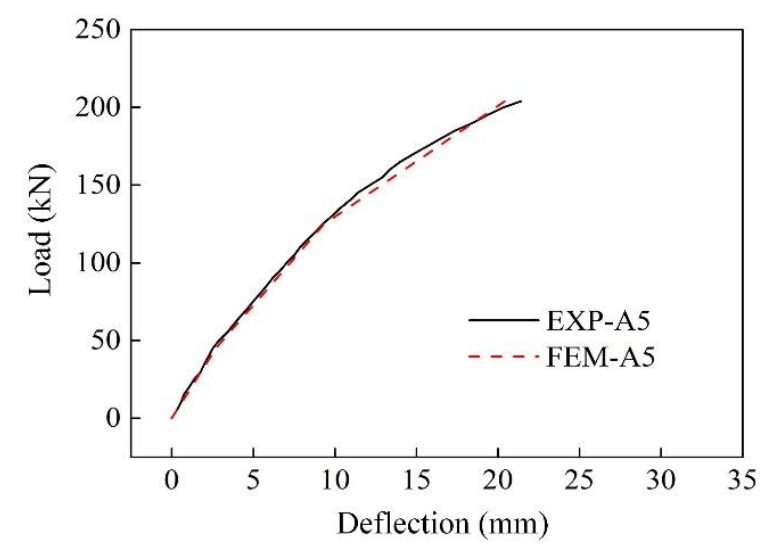

(a) Load and deflection curve

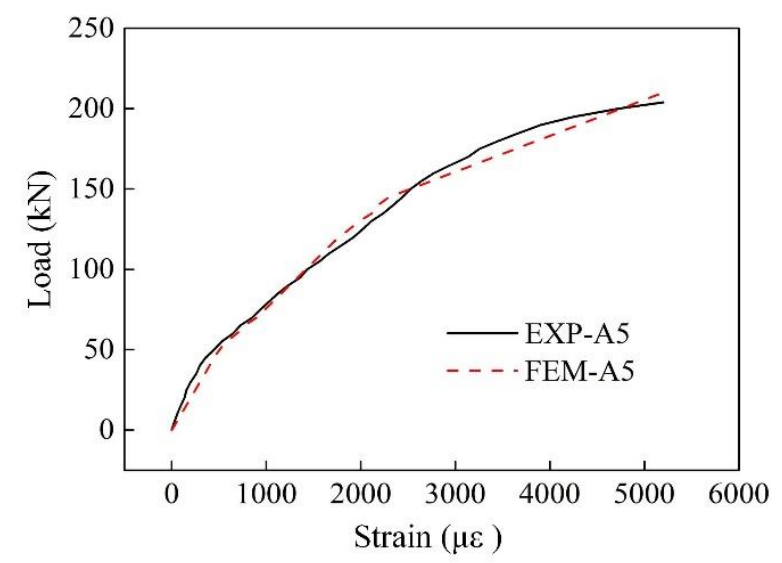

(c) Load and strain curve (steel bar)

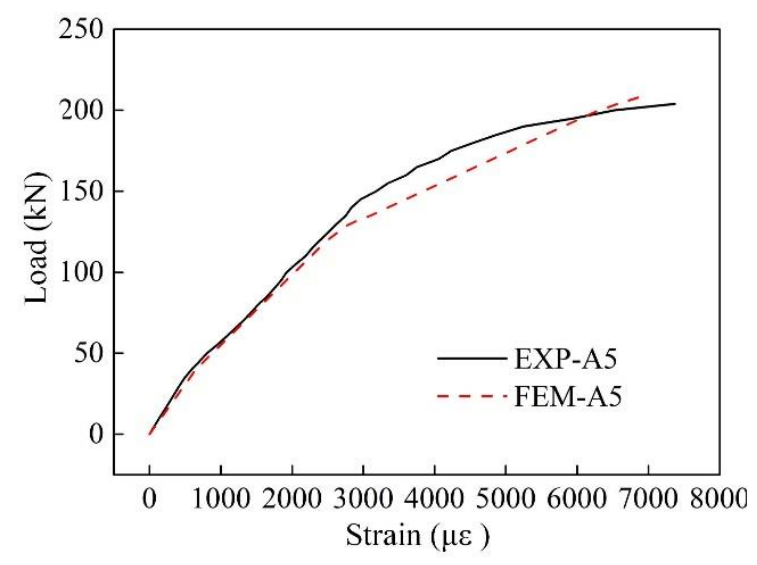

(b) Load and PUC strain curve

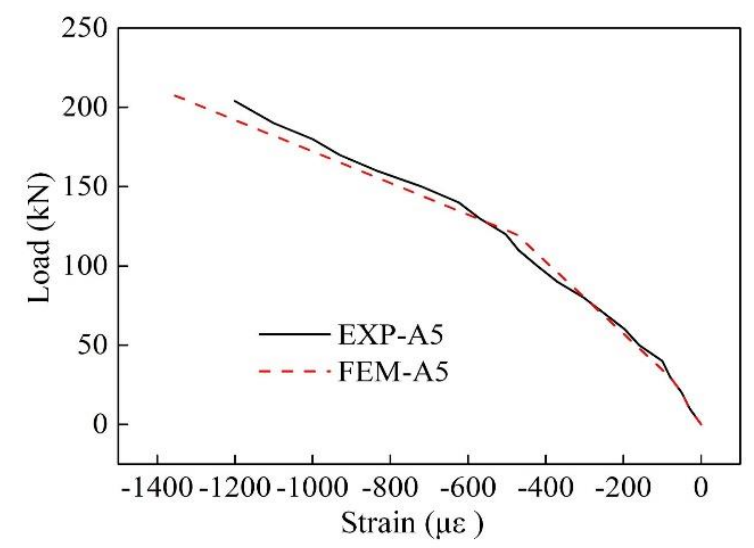

(d) Load and concrete strain curve

Fig.20 - Simulation results of Abaqus and test results (specimen A5)

Based on the simulation analysis of the form of reinforcement with 5 wire ropes embedded in $20 \mathrm{~mm}$ thick polyurethane cement, finite element simulation analysis was conducted for reinforced girder A8 with different thickness of polyurethane cement and reinforced girder A9 with different number of pre-stressed wire ropes. Finite element simulation curves and test curves were plotted. The finite element calculation curves of specimens A8 and A9 are compared with the test curves in Figure 21 and Figure 22. The load-deflection curve, loadbottom PUC strain curve, load-tension zone reinforcement strain curve, and load-compression zone concrete strain curve in the span calculated by the finite element are similar to the test results. It shows that the calculation model can better reflect the force process of the member. Throughout the loading process, especially after yielding of the reinforcement, the load carrying capacity of the member is increased to a large extent due to the presence of the polyurethane cement material. The calculation results are convincing and can be used to supplement the reinforcement test and the in-depth study of the reinforcement test girder. 


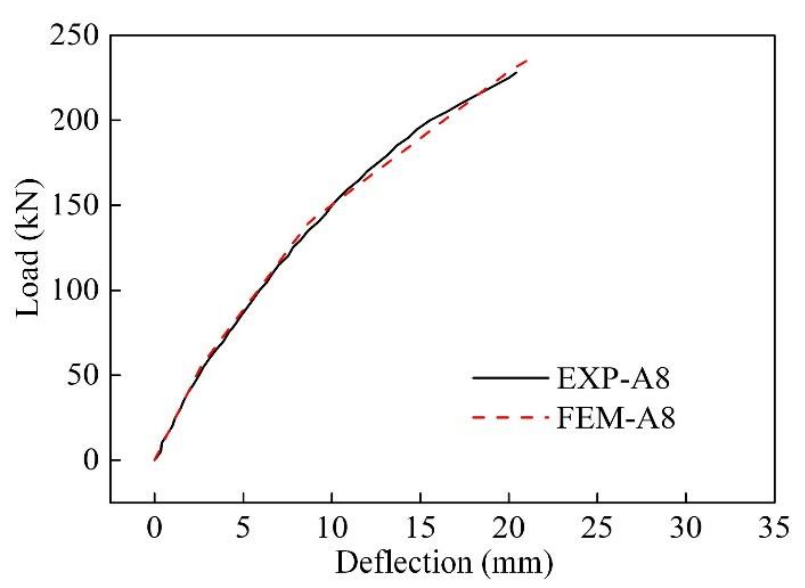

(a) Load and deflection curve

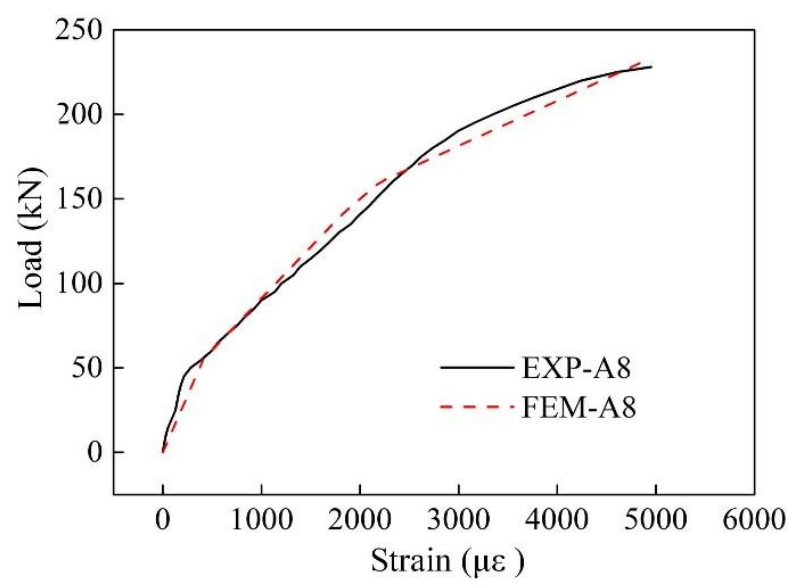

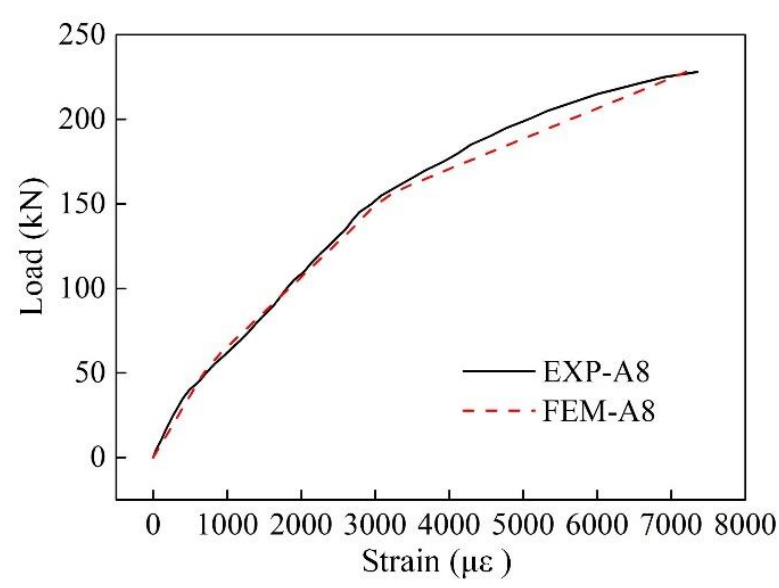

(b) Load and strain curve (PUC)

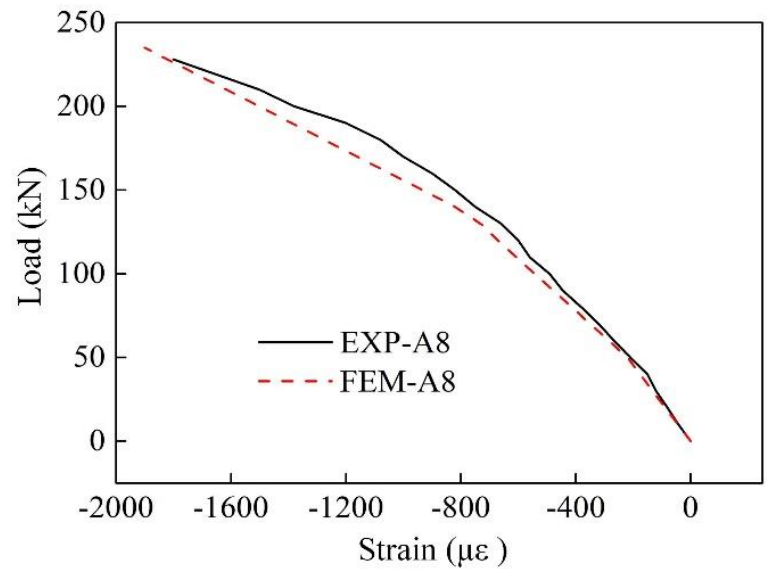

(c) Load and strain curve (steel bar) (d) Load and compressive strain curve (concrete)

Fig.21 - Simulation results of Abaqus and test results (specimen A8)

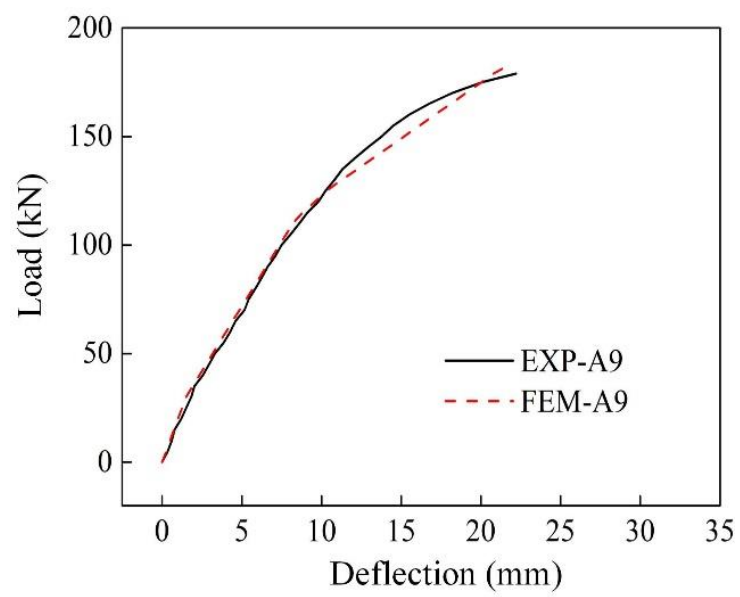

(a) Load and deflection curve

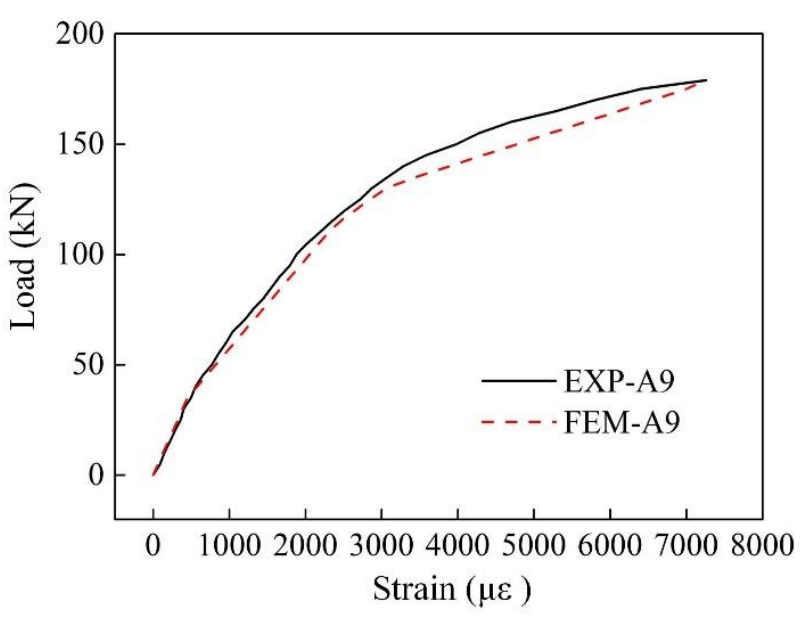

(b) Load and strain curve (PUC) 


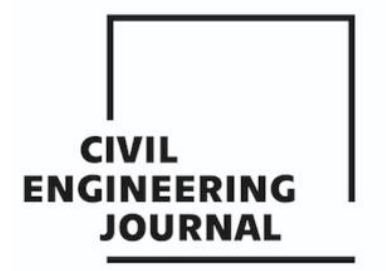

Article no. 69

THE CIVIL ENGINEERING JOURNAL 4-2021
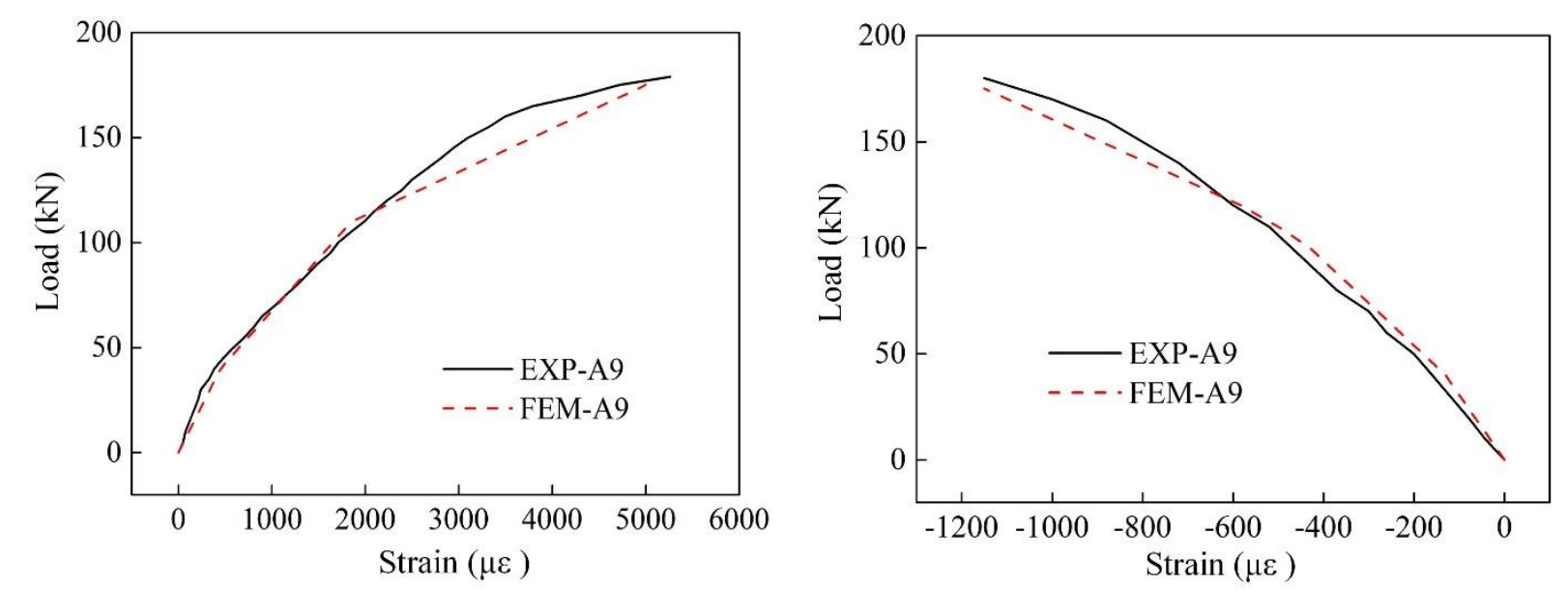

(c) Load and strain curve (steel bar) (d) Load and compressive strain curve (concrete) Fig.22 - Simulation results of Abaqus and test results (specimen A9)

\section{Effect of concrete strength on reinforcement performance}

The concrete strengths were $30 \mathrm{MPa}, 40 \mathrm{MPa}$ and $50 \mathrm{MPa}$ respectively. The strengthening girders were identical to those of the test girders, with a reinforcement rate of $0.91 \%$. The reinforcement layer was a $20 \mathrm{~mm}$ thick polyurethane cement material embedded with five prestressing steel ropes, and the loading method was symmetrical loading at two points. The calculation results of FEA are shown in Table 6.

Tab.6 - Calculation table of influence of concrete strength on flexural reinforcement

\begin{tabular}{|c|c|c|c|c|}
\hline $\begin{array}{c}\text { Specimen } \\
\text { number }\end{array}$ & $\begin{array}{c}\text { Yield strength } \\
(\mathrm{kN})\end{array}$ & $\begin{array}{c}\text { Yield deflection } \\
(\mathrm{mm})\end{array}$ & $\begin{array}{c}\text { Ultimate strength } \\
(\mathrm{kN})\end{array}$ & $\begin{array}{c}\text { Fracture deflection of } \\
\text { reinforcement layer }(\mathrm{mm})\end{array}$ \\
\hline FEM-C30 & 120.00 & 8.82 & 200.40 & 19.98 \\
\hline FEM-C40 & 123.00 & 9.03 & 208.00 & 20.40 \\
\hline FEM-C50 & 125.00 & 9.11 & 212.20 & 20.63 \\
\hline
\end{tabular}

As can be seen from Table 6, the yield strength of reinforced girders increases slightly with the improvement of concrete strength. Taking C30 concrete members as a reference, the yield strength increases by $2.5 \%$ and $4.1 \%$ respectively, when the deflection values are also very close. The increase of yield strength was 3.79\% and $5.89 \%$ for C30 concrete members as reference, the fracture deflection of the reinforcement layer of the members increased with the improvement of concrete strength of the reinforced members. The ultimate deflection of the members increased by $2.10 \%$ and $3.25 \%$ respectively.

The simulation results of concrete reinforced girders with different strengths are shown in Figure 23. The deflection trends of reinforced girders of different strengths are approximately the same. Similarly, the strain trends for steel and polyurethane cement are essentially the same, with the material curves almost coinciding for reinforced girders of different strengths, but with a slight increase in the maximum strain of the material at damage as the strength 
increases. When damage to the reinforcement layer occurs, the reinforced girder with the highest concrete strength has the highest load-bearing capacity.

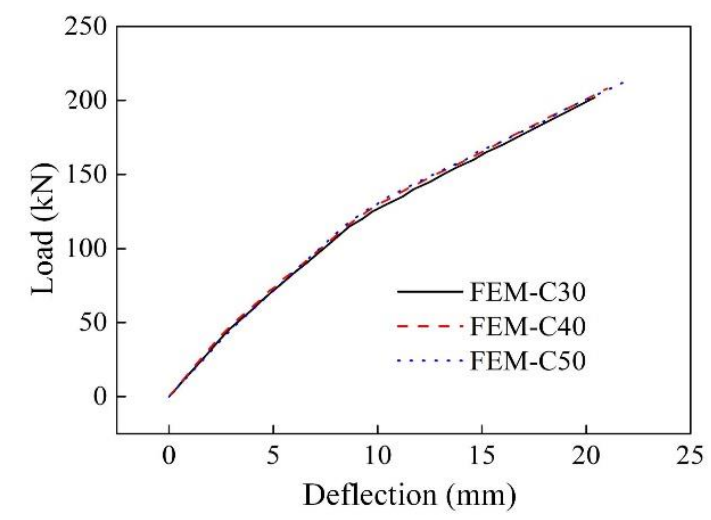

(a) Load and deflection curve

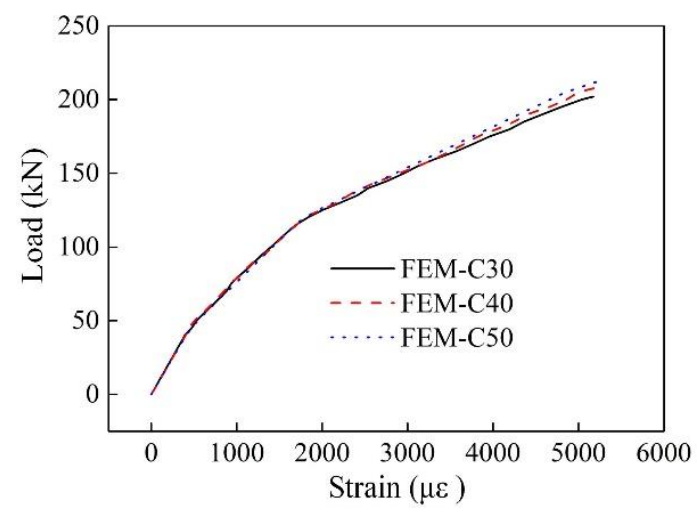

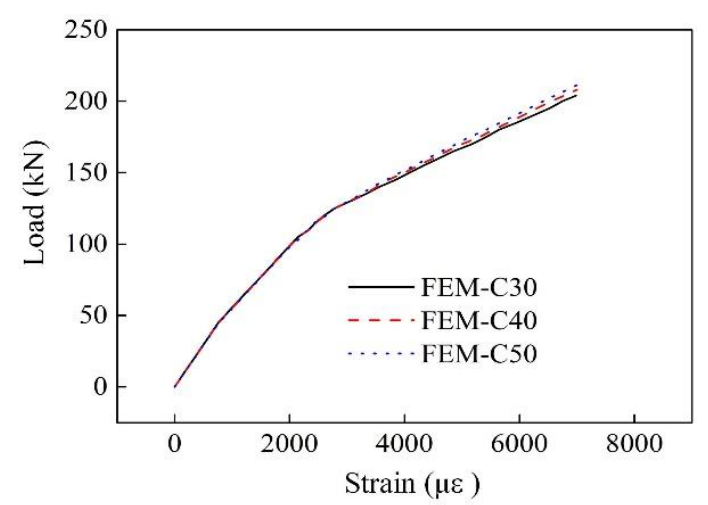

(b) Load and PUC strain curve

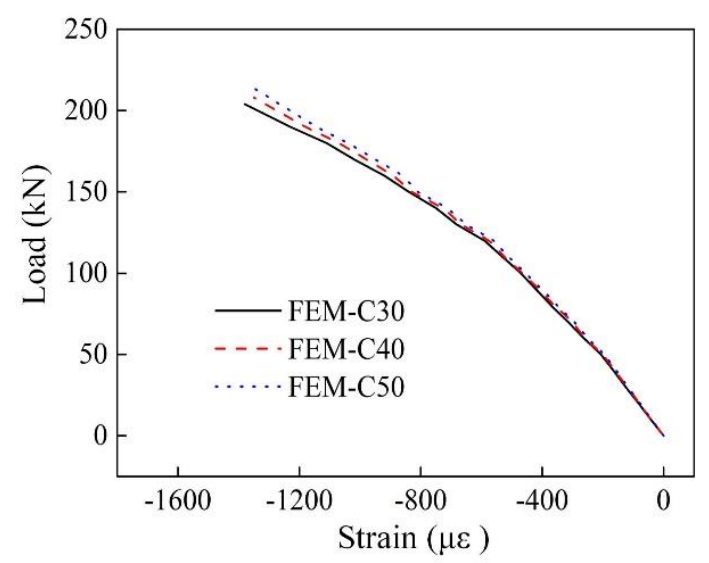

(c) Load and reinforcement strain curve (d) Load and concrete compressive strain curve Fig.23 - Simulation results of Abaqus (Specimens of different concrete strength)

\section{Effect of original girder reinforcement rate on reinforcement performance}

In order to study the effect of reinforcement rate of main reinforcement on the performance of reinforced girders, the reinforcement rates in the model were taken as $0.91 \%, 1.82 \%$ and $2.73 \%$, respectively. The concrete strength is adopted according to the values of flexural reinforcement tests in Chapter 3, and the reinforcement layer is 5 prestressing steel ropes embedded in $20 \mathrm{~mm}$ thickness of polyurethane cement material, loaded symmetrically at two points in the span. The finite element calculation results are shown in Table 7. 
Article no. 69

CIVIL

ENGINEERING JOURNAL

THE CIVIL ENGINEERING JOURNAL 4-2021

Tab. 7 - Calculation table of influence of reinforcement ratio on flexural reinforcement

\begin{tabular}{|c|c|c|c|c|}
\hline $\begin{array}{c}\text { Specimen } \\
\text { number }\end{array}$ & $\begin{array}{c}\text { Yield strength } \\
(\mathrm{kN})\end{array}$ & $\begin{array}{c}\text { Yield deflection } \\
(\mathrm{mm})\end{array}$ & $\begin{array}{c}\text { Ultimate } \\
\text { strength }(\mathrm{kN})\end{array}$ & $\begin{array}{c}\text { Fracture deflection of } \\
\text { reinforcement layer }(\mathrm{mm})\end{array}$ \\
\hline FEM-0.91 & 123 & 208 & 9.03 & 20.4 \\
\hline FEM-1.35 & 159.7 & 249.3 & 10.22 & 20.2 \\
\hline FEM-1.82 & 204 & 299.2 & 9.39 & 20.53 \\
\hline
\end{tabular}

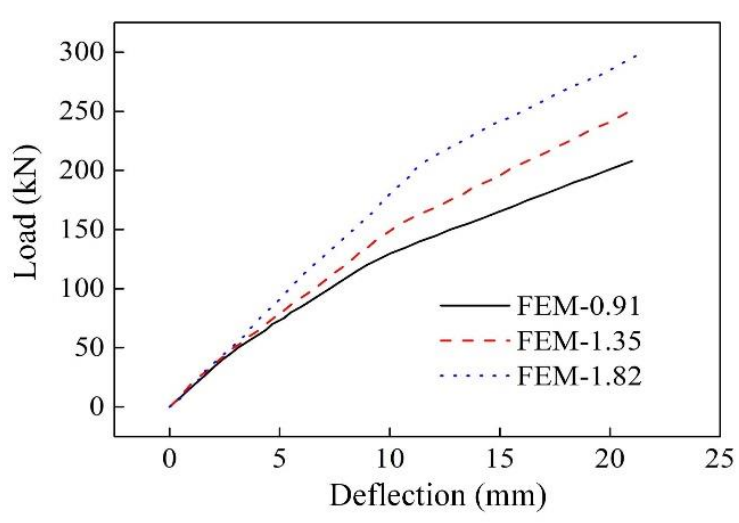

(a) Load and deflection curve

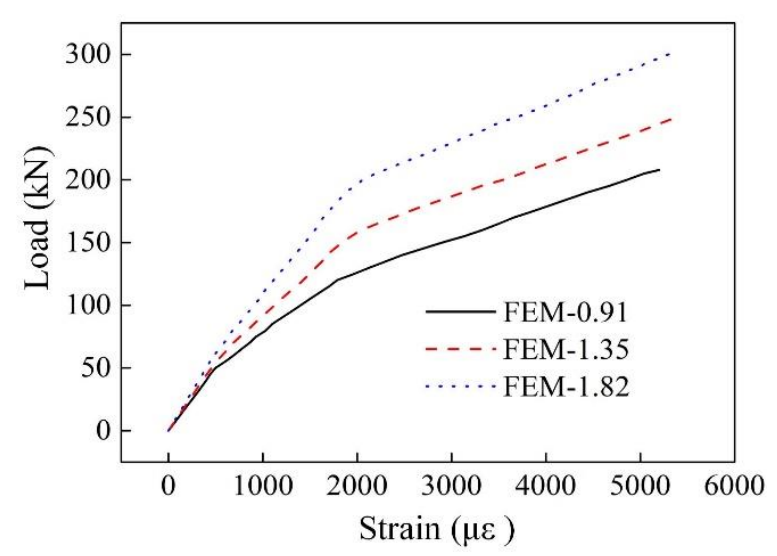

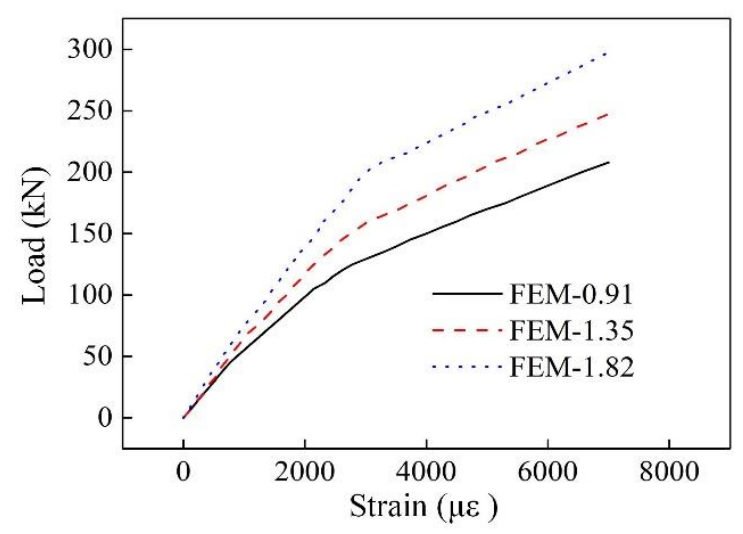

(b) Load and PUC strain curve

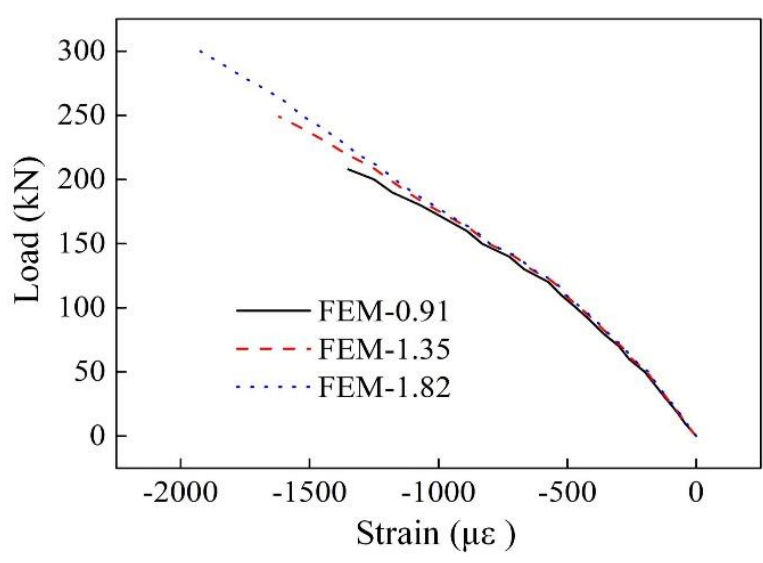

(c) Load and reinforcement strain curve (d) Load and concrete compressive strain curve Fig.24 - Simulation results of Abaqus (Specimens of different reinforcement ratio)

From Table 7, it can be seen that the load carrying capacity of reinforced girders varies significantly with the increase in the reinforcement rate of longitudinal bars, and the yield loads of girders with reinforcement rate of $1.82 \%$ and $1.35 \%$ increase by $29.84 \%$ and $65.85 \%$, respectively, compared to girders with reinforcement rate of $0.91 \%$, and the yield deflections of girders with reinforcement rate of $1.82 \%$ and $1.35 \%$ increase by $13.18 \%$ and $3.99 \%$, respectively. The ultimate bearing capacity of the girders at reinforcement layer fracture damage increased by $19.86 \%$ and $43.85 \%$ with the increase of reinforcement rate, and the 


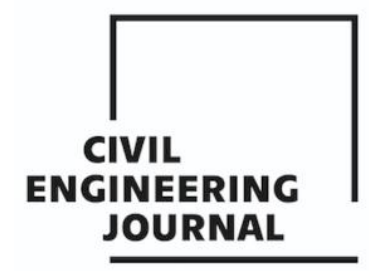

Article no. 69

THE CIVIL ENGINEERING JOURNAL 4-2021

ultimate deflection did not change much with the increase of reinforcement rate, which were $0.98 \%$ and $0.64 \%$, respectively.

The finite element calculation results of the reinforced girder with different reinforcement rates are shown in Figure 24. As the reinforcement rate increases the concrete strain of the member increases, and the member with the most longitudinal reinforcement exhibits the greatest load-bearing capacity when the final damage occurs. The strain of polyurethane cement and steel reinforcement becomes larger with increasing reinforcement ratio and the load carrying capacity of the member increases.

\section{CONCLUSION}

In this paper, 7 T-girder specimens were studied in flexural tests. The effect of each design parameter on the reinforcement effect was elaborated through the experimental analysis of the flexural performance of polyurethane cement prestressed steel wire rope reinforced girders. Through the ABAQUS finite element program to establish a model for numerical simulation, and the actual test for flexural parameters analysis compared to the following conclusions:

(1) Compared with prestressing steel wire rope reinforcement, polyurethane cementprestressing steel wire rope reinforcement can effectively improve the yield strength and ultimate strength of the reinforced girder. Taking girder A5 (20 mm thick polyurethane cement) as an example, the yield load and ultimate load increased by $61.5 \%$ and $102.3 \%$ compared with CB control girder. While the yield load and ultimate load of girder A2 (20 mm thick cement mortar) increased by $30.1 \%$ and $39.9 \%$, far less effective than the polyurethane cement prestressed steel wire rope reinforcement.

(2) A reasonable finite element model for flexural reinforcement of T-girder is established. The simulation results are similar to the test results. The finite element simulation results are in good agreement with the flexural reinforcement test, the ABAQUS program is calculated correctly, and the established finite element reinforcement model is reasonable.

(3) For different strengths of concrete, the yield load increases slightly as the concrete strength of the reinforced girder increases, but the value of yield deflection is close. Taking the C30 concrete members as reference, the yield strength increases by $3.79 \%$ and $5.89 \%$, and the ultimate deflection and ultimate bearing capacity increase by the same trend of $2.10 \%$ and $3.25 \%$, respectively.

(4) For T-girders with different reinforcement ratios, the bearing capacity of reinforced girders changes significantly with the increase of longitudinal reinforcement ratio. The yield loads of girders with reinforcement ratio of $1.82 \%$ and $1.35 \%$ increase by $29.84 \%$ and $65.85 \%$, respectively, and the yield deflections increase by $13.18 \%$ and $3.99 \%$, respectively, compared with those of girders with reinforcement ratio of $0.91 \%$. The ultimate deflection does not change much with the increase of reinforcement rate, which is $-0.98 \%$ and $0.64 \%$ respectively.

\section{REFERENCES}

[1] Zhou, Y. 2007. Practice and discuss of bridge disease measuring and punishing methods. Urban Roads Bridges \& Flood Control.

[2] Liu, G. J. 2008. The analysis of T-girder bridge diseases and reinforcement technology. Shanxi Architecture.

[3] Ye, W., Ji, L., Highway, S. O., \& University, C. 2014. Disease analysis and reinforcement method for a simply supported t-shaped girder bridge. Modern Transportation Technology. 


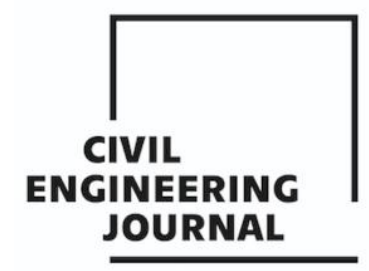

Article no. 69

THE CIVIL ENGINEERING JOURNAL 4-2021

[4] Wang, Y. M. 2012. Analysis of maintenance and reinforcement about bridge pier and abutment. Transportation Standardization.

[5] Fan, H. B. 2010. Inspection and maintenance \& reinforcement of state-province artery bridge system. Enterprise Science and Technology \& Development.

[6] Chen, W. C., \& Jian-Qin, M. A. 2006. Discussion on main diseases of the prestressed continuous rigid-frame bridge and its maintenance and reinforcement mornitoring. Communications

Standardization.

[7] Laane, A., \& Lebet, J. P. 2005. Available rotation capacity of composite bridge plate girders under negative moment and shear. Journal of Constructional Steel Research, 61(3), 305-327.

[8] RA Parmelee, RB Corotis. 2004. Analytical and experimental evaluation of existing florida dot bridges. finite element method.

[9] Huang, S. N., Lu, X. Z., Zheng, J. C., \& Zhu, W. 2012. Overload-induced progressive collapse simulation for a reinforced concrete arch bridge. Engineering Mechanics, 29(SUPPL. 2).

[10] Ghoneim, G. , \& Ghali, A. . 2011. Nonlinear analysis of concrete structures. Canadian Journal of Civil Engineering, 9(3), 489-501.

[11] Dharaneepathy, M. V., \& Anandavalli, N.. 2008. Nonlinear analysis of shock-loaded reinforced concrete structures. International Journal of Structural Stability \& Dynamics, 4(02), 223-236.

[12] Cao, M. 2012. Research on damage plastic calculation method of abaqus concrete damaged plasticity model. Transportation Standardization.

[13] Yuan, M., Yuan, S., \& Yan, D. H. 2008. Analysis on plastic damage of prestressed concrete box girder. Journal of Highway and Transportation Research and Development.

[14] Zhang, H. X., \& Lu-Yuan, H. E. 2014. Numerical simulation analysis on bond-slip behavior of concrete strengthened with near-surface mounted cfrp bars based on abaqus. Engineering Mechanics.

[15] Chuan-Xue, X. U., \& Liu, F. 2016. Analysis of the influence factors of long-term rigidity of girder by external prestressing. Jiangsu Construction.

[16] Zhang, Z., \& iu, Y. 2011. Concrete damaged plasticity model in abaqus. Building Structure.

[17] China Academy of Building Research. 2016. GB50010-2010 Code for design of concrete structures. Beijing: China Architecture \& Building Press.

[18] Cao, M. 2012. Research on damage plastic calculation method of abaqus concrete damaged plasticity model. Transportation Standardization.

[19] V Birtel, P Mark. 2006. Parameterised finite element modelling of RC girder shear failure.

[20] Yuan, M., Yuan, S., \& Yan, D. H. Analysis on plastic damage of prestressed concrete box girder. Journal of Highway and Transportation Research and Development.

[21] Zhang, K., \& Sun, Q. 2018. Experimental study of reinforced concrete t-girders strengthened with a composite of prestressed steel wire ropes embedded in polyurethane cement (PSWR-PUC). International Journal of Civil Engineering,Transaction A:Civil Engineering, 16(9), 1109-1123.

[22] Zhang, K., Qi, T., Zhu, Z., Xue, X., \& Shen, X. 2021. Strengthening of a Reinforced Concrete Bridge with a Composite of Prestressed Steel Wire Ropes Embedded in Polyurethane Cement. Journal of Performance of Constructed Facilities, 35(5), 04021063.

[23] Zhang, K., \& Sun, Q. 2019. Bending Fatigue Properities Research of Polyurethane Cement (PUC). Civil Engineering Journal, (2). 